\title{
Analysis of Students' Satisfaction on Quality Education at Government Colleges in Lahore Division
}

\author{
Alia Sadiq ${ }^{1}$, Mahr Muhammad Saeed Akhter ${ }^{2}$
}

\begin{abstract}
Quality education is the most important and considered as a pivot for progress to uplift the lives of a nation. The success of the educational institutions relies not only on quality education but also on the satisfaction of students. This study aims to explore the relationship between quality education and student satisfaction and difference regarding demographic variables at college level in Lahore Division. All the students from 80 government degree colleges of Lahore division were the population of this study. The study was descriptive in nature and has followed correlational research design. By using simple random sampling technique forty government degree colleges (50\% of the population) were selected as sample by adopting lottery method. Self-constructed questionnaires for students "Quality Education Assessment Scale" and "Student Satisfaction Assessment Scale" were the instruments of this study. Appropriate statistical analysis techniques were used on the collected data. Product Moment Correlation Co-efficient were used for determining quality education and student satisfaction. Independent sample ttest was applied to find the difference between demographic variables. Results of the study indicated that quality education exits in colleges according to students. There was moderate significant correlation between two variables $(r=.625$, $p<.05$ ) of the quality education and the students' satisfaction. As compared to male students, the female students' had perceived more satisfaction towards students' satisfaction. Both intermediate and bachelor students' had perceived almost same level regarding students' satisfaction.
\end{abstract}

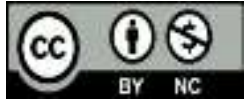

Keywords: Quality Education, Student Satisfaction

\section{Introduction}

Colleges are considered abode to bring up the upcoming generations educationally and provide them a chance to set environment for the development of the nation and country (Pascarella \& Terenzini, 2006). Colleges are supposed to provide supportive and conducive quality education to the students for their

\footnotetext{
${ }^{1}$ Ph.D Scholar, Institute of Education and Research, University of the Punjab, Lahore, Email:ms_saadiq@hotmail.com

${ }^{2}$ Institute of Education and Research, University of the Punjab, Lahore

Email: mahrsaeed@gmail.com
} 
success in practical life. According to the Comm and Mathaisel (2000) in most of the educational researches the students are considered as customers. Researchers evaluated the satisfaction and dissatisfaction level of students with the study programs in higher educational institutions; researches have been proved that now quality has to be begun considering the academic satisfaction (Comm \& Mathaisel, 2003).

It is mandatory to assess the quality of education continuously that directly affects the students' performance because they are considered as consumers as well as customers of education. Students are not only the customers but also they are the product of educational institutions. The perspectives of students on various features of higher education encounters need aid to detect the standard of education. Standards of education empower those administration supplier and also different stakeholders to do evaluation on features and traits in specific institutions (Hill, Lomas, \& Macgregor, 2003).

There are numerous other studies with special focus on the students' satisfaction in different perspectives of education system (Fornell, 1992; Boulding, Kalra, Staelin \& Zeithaml, 1993; Anderson, Fomell \& Lehmann, 1994). There is broad spread literature on quality education and students' satisfaction out of the teaching and learning system. These international scholars published different aspects of the subject under discussion in this research article.

A brief review of these researches presents a diverse picture. A study was conducted to investigate the quality of education at intermediate level by Shahzad (2007). Guolla (1999) researched to find out relationship between quality education and student satisfaction. Munteanu, Ceobanu, Bobâlcă and Anton (2010) conducted a research on the analysis on student satisfaction in higher education context. The researcher found the gap that there is no research related to the students' satisfaction in Lahore division at college level. Past researches cater the school level; inter level and university level of education in different contexts of the similar topic. It is an attempt to fill this research gap.

\subsection{Objectives of the Study}

The objectives of this study were:

1. To explore the relationship between quality education and student satisfaction at college level in Lahore division.

2. To investigate the difference of students regarding their satisfaction based on their demographic variables (gender and programme) at college level in Lahore division.

\subsection{Research Questions}

The following research questions were posed to conduct the study: 
1) Is there any significant relationship between quality education and students' satisfaction at college level in Lahore division?

2) Is there any significant difference between male and female regarding students' satisfaction at college level in Lahore division?

3) Is there any significant program wise difference regarding students' satisfaction at college level in Lahore division?

\subsection{Significance of the Study}

It is hoped that this study is beneficial for the college staff and management to improve the quality of education keeping in mind the aspects of students' satisfaction. The results of improving quality in education and students' satisfaction are beneficial for the coming generations of students. It added to the knowledge of the college education and aspects of its quality and student satisfaction. There are not any big claims of utilization of this study but it is hoped that this research is stimulation for further research with special focus on quality education and students' satisfaction at college level in Pakistan. Future researchers in sequence of this research area may get guidance out of this study.

\section{Literature Review}

Quality is always seen from the users' perspective. Quality education plays an important role in students' satisfaction. This study has among its objectives to explore and elaborate the relationship and influence of quality standards introduced by the Higher Education Commission of Pakistan for the college sector institutions in the geographic region of Pakistan. These are nine indicators in the following (HEC, 2011):

- Vision, Mission and Goals

- Academic Programmes and Evaluation

- Student Admission and Progression

- Academic Faculty and Non-Academic Staff

- Physical Infrastructure, Academic Facilities and Learning Resources

- Organization, Governance and Financial Management

- Research

- Public Disclosure and Transparency

- Community Link and Outreach

These are students who are users or beneficiaries who set parameters for quality. When we talk about education then these are students who are ultimate users or beneficiaries of education. Quality of education can only be seen through lenses of students' abilities or capabilities that are embodied in them due to their education and teachings in the education system.

Scholarly research and literature has a considerable coverage of different 
aspects of quality education. Geotsch and Davis (2009) defined quality in terms of a combination of items, people, procedures, situations and their mutual interactions that helps in meeting the desires and needs of users. Quality in education sector have been defined by Cheng (1995) that stated educational quality in a system of input, processes and output that are used in provision of services that are compatible to the internal and external strategies to meet the implicit and explicit expectations out of education system.

Most of the studies focused on quality education in a combination of educational institutions perspective and students' perspective. Abidin (2015) focused on the perception differences among internal and external stakeholders regarding quality of higher education. His study considered students as external stakeholders and teachers as internal stakeholders. Results of this quantitative study highlighted that students and teachers have entirely different perceptions regarding quality of education on higher education level. Perceptions of teachers on various dimensions of quality education are much higher in comparison to the perceptions of students. This study covered the perspective of students' satisfaction and quality education that are the major themes in this study with a population of college students in Lahore division.

Monazza, Rabea, Shenila, Rose, Vignoles and Whitaker (2019) conducted a survey to collect data related to teaching and learning in the contexts of India and Pakistan. Researchers explored schools difference in terms of students' learning and achievement. As a whole, their study suggested various recommendations related to teachers' attitude, knowledge and teaching techniques and methods for considerable impact of their students' learning.

Literature review related to research and studies on quality education has revealed that there are wide spread literature on quality education. A research article published by Budiharso and Tarman (2020) has its focus on the quality education. Researchers in their study found that there is not any significant effect of working condition on the quality of education. However they explored that are employability and faculty retention that have their significant effects on the quality of education in higher education institutions. Researchers have explicit description of the limitations of their study because they conducted their study in a population in the geographic circumstances of Indonesia whiles other regions of the world may have their different results due to specific socio, cultural and political circumstances.

Belash, Popov, Ryzhov, Ryaskov, Shaposhnikov, and Shestiplalov (2015) published a study on the quality education at university level education. Their study is related to the aspects of satisfaction including the satisfaction of students out of the quality education. Quality constituents in their study were 
comprised of the quality of academic process, assessment of teachers by their students, students' assessment of sufficiency of course knowledge and skills, course utility for students, quality of studies, and level of teaching. Their research is in line with the quality assessment parameters set by the Higher Education Commission of Pakistan as feedback for quality education is given specific importance for quality education.

Most of the studies focused on schools and university education. There was less work about college sector education and its quality related issues. Few studies in Pakistan have their focus on comparatively smaller geographical units but there is scarcity of literature about quality education at colleges sector. It is identified gap for this research on the quality education at college level in Lahore division.

Students are major beneficiaries in teaching and learning initiatives in education system. Green, Hood and Neumann (2015) published their study on students' satisfaction in a single subject of Psychology at Australian university level. It is a literature review based study in which researchers collected data from the available databases and reference lists of relevant literature. Variables of interest in their research are exactly similar to the variables in this research article. Research conducted by Zamberi (2015) is of student satisfaction in Malaysian context. Data in this study is based on interviews from the students who were studying at international campuses of Australian, Indian and Britain universities.

Pakistani researchers also published on students' satisfaction and a lot of their related aspects. There is no scarcity of research that covered different issues related to the language of instructions for students. Kamal and Saeed (2018) published their research on students' satisfaction in university context of Pakistan. Their focus was on mutual relationship of students' English proficiency, academic achievement and satisfaction on teacher feedback. Many of Pakistani researchers highlighted issues of service quality and their relation to students' satisfaction. One among these studies is of Saima, Kamran, Abeer and Rashid (2017). Aslam, Rehman, Imran and Muqadas (2016) published results of their research from the private sector universities in Pakistan. Few researchers in Pakistan emphasized the satisfaction of students' perception for their overall satisfaction from the educational institution. Rehana et al. (2016) published their research on students' perceptions at the Aga Khan University Medical College.

Literature review on students' satisfaction revealed that there are a wide spread literature on many aspects of students' satisfaction in geographic perspective of Pakistan. A short view of the students' satisfaction in quality 
education at college level in Lahore division has not been covered by any of the studies. Therefore it has scope of research for this study.

\subsection{Research Design}

\section{Research Methodology}

The study was descriptive in nature as it described a phenomena related to the college students. Quantitative research method and correlational research design was used to conduct this study. In descriptive research, characteristics of a phenomenon or population are studied that are used for statistical calculations. Before writing descriptive research, survey research is regarded the best approach (Shields \& Rangarajan, 2013). Correlational research is part of the quantitative methods of research that determine the relationship between two or more variables from the same population group (Creswell, 2012).

\subsection{Population of the Study}

All the students in 80 government degree colleges of Lahore division were the population of the study. Total number of students were 1, 50,682 (60190 male \& 90492 female) in government degree colleges of Lahore division. A list of these colleges, total number of teachers and students in these colleges were collected from Higher Education Department, Govt. of the Punjab (Higher Education Department, 2016). The reason for selecting Lahore division as population was that it is considered a hub of education in Pakistan.

\subsection{Sample \& Sampling Technique}

Simple random sampling technique was employed in sampling the population of this study. There were total 80 colleges in Lahore division. Students in these 80 colleges were included in the population of this study. 40 government degree colleges ( $50 \%$ of total colleges) were selected through lottery method to choose sample. Onward sampling was done randomly by adopting lottery method also and 100 students were selected from each college out of the already selected 40 government degree colleges situated in the demographic region of the Lahore division. In this way, 4000 students including both male and female from amongst these government degree colleges of Lahore division were taken as sample for this study.

\subsection{Instrumentation}

Two instruments were used in this study. Researcher developed the instrument for quality education by keeping in mind the minimum standards of quality by Higher Education. The reliability of this instrument was .91. There were 35 statements in the second part of this instrument. Following are the indicators of this "Quality Education Assessment Scale":

1) Vision, Mission \& Goals

2) Academic Programmes and Evaluation 
3) Student Admission and Progression

4) Academic Faculty and Non-Academic Staff

5) Physical Infrastructure, Academic Facilities and Learning Resources

6) Organization, Governance and Financial Management

7) Research

8) Public Disclosure and Transparency

9) Community Link and Outreach

For student satisfaction the instrument "Student Satisfaction Assessment Scale" was also developed by the researcher after reading the previous studies and considering the research objectives. The indicators of this instrument were determined after reading literature. Reliability of this instrument was .86 after pilot testing. There were 22 statements in the second part of this instrument. Following were the indicators of this self-developed instrument:

1) Admission Process

2) Academic Programmes

3) Quality of Teaching

4) Student Teacher Relation

5) Management

6) Contact with Parents

7) Facilities

\subsection{Collection of Data}

Data collection was done through e-mail and during personal visits to the colleges.

\section{Data Analysis \& Interpretation}

Product Moment Correlation Co-efficient was applied to find out the relationship between students' satisfaction and quality education. Independent sample t-test was applied to find out gender and programme wise difference regarding students' satisfaction as it is used to compare the means of two groups. Due to normal distribution of data, these data sets are suitable for the application of parametric tests for its statistical analysis.

\section{Research Question 1}

Is there any significant relationship between quality education and students' satisfaction at college level in Lahore division?

To look into the relationship between quality education and students' satisfaction the statistical test was Pearson Product Moment Correlation $(r)$. It is the parametric test that is performed on the normally distributed data. There is need to check the data distribution as preliminary analysis of given data. Preliminary analyses were performed to ensure the issues of validation of the assumptions of normality, linearity and homoscedasticity. After the preliminary 
tests of available data, Pearson correlation test was applied. The results this statistical test is given in the table below;

Table 4.1

Relationship between Quality Education and Students' Satisfaction

\begin{tabular}{lllll}
\hline Measure & Mean & SD & 1 & 2 \\
\hline 1. Quality Education & 126.55 & 20.20 & - & \\
2. Student satisfaction & 74.89 & 14.38 & & $.625^{*}$ \\
\hline
\end{tabular}

$* p<0.05$ (Sig. 2-tailed)

Results given in the table 4.1 showed that there was moderate significant correlation between two variables $(r=.625, p<.05)$ of the quality education and the students' satisfaction. It means that there are moderate effects of the quality education on the students' satisfaction in the government colleges situated in the Lahore division. The significance of the positive correlation indicated that the improvements in the quality education help in students' satisfaction and vice versa. It means if there is improvement or decline occurs in quality education in colleges, the students' satisfaction will be automatically improved or declined. In those colleges where quality education is on peak the students were more satisfied than the students of those colleges where quality education is no up to the mark.

\section{Research Question 2}

Is there any significant difference between male and female regarding students' satisfaction at college level in Lahore division?

Table 4.2

Difference between Male and Female Regarding Students' Satisfaction

\begin{tabular}{lllllll}
\hline Variables & Gender & $N$ & $M$ & $S D$ & $t$ & Sig. \\
\hline Admission Process & Male & 1730 & 7.31 & 2.229 & -3.081 & $.002^{*}$ \\
& Female & 1820 & 7.92 & 1.445 & & \\
Academic Programs & Male & 1730 & 9.80 & 2.544 & -4.380 & $.000^{*}$ \\
& Female & 1820 & 10.93 & 2.319 & & \\
Quality of Teaching & Male & 1720 & 12.97 & 3.274 & -6.155 & $.000^{*}$ \\
& Female & 1820 & 15.06 & 3.113 & & \\
Student Teacher Relation & Male & 1730 & 14.40 & 3.573 & -3.655 & $.000^{*}$ \\
& Female & 1820 & 15.66 & 2.936 & & \\
Management & Male & 1730 & 8.46 & 2.974 & -4.124 & $.000^{*}$ \\
& Female & 1820 & 9.74 & 2.897 & & \\
Contact with Parents & Male & 1730 & 11.07 & 3.841 & -4.750 & $.000^{*}$ \\
& Female & 1820 & 12.87 & 3.308 & & \\
Facilities & Male & 1730 & 6.71 & 2.367 & .153 & .879 \\
Total Student Satisfaction & Female & 1820 & 6.68 & 1.964 & & \\
& Male & 1720 & 70.69 & 15.432 & -5.569 & $.000^{*}$ \\
& Female & 1820 & 78.87 & 12.071 & & \\
\hline
\end{tabular}


*. $\mathrm{p}<=0.05$

Independent sample $t$-test was applied to compare male and female students' perception towards satisfaction factors. The $t$-values and mean scores reflected that a meaningful difference was found in the perception of male and female students' regarding admission process, academic programs, quality of teaching, student teacher relation, management, contact with parents, and overall student satisfaction as the $p$-values $<0.05$

As compared to male students, the female students' had perceived more satisfaction towards admission process, academic programs, quality of teaching, student teacher relation, management, contact with parents, and overall students' satisfaction. However the male and female students perceived equally towards facilities factor as the $p>.05$. It means that female colleges were more focused to fulfill the students' satisfaction indicators than in male colleges in Lahore division. While facilities indicator was perceived same by male and female students which disclosed that in govt. colleges same facilities were provided in male and female colleges.

\section{Research Question 3}

Is there any significant program difference regarding students' satisfaction at college level in Lahore division?

Differences of students' satisfaction with respect to their program of education were calculated in response to this research question. Results of data analysis related to this research question are given in the table 3 below;

Table 4.3

Program wise Difference regarding Students' Satisfaction

\begin{tabular}{lllllll}
\hline Variables & Locality & $N$ & $M$ & $S D$ & $t$ & Sig. \\
\hline Admission Process & Inter & 450 & 7.91 & 1.755 & .975 & .330 \\
& Bachelor & 3120 & 7.58 & 1.916 & & \\
Academic Programs & Inter & 430 & 10.63 & 2.462 & .648 & .518 \\
& Bachelor & 3120 & 10.34 & 2.508 & & \\
Quality of Teaching & Inter & 430 & 15.43 & 2.821 & 2.640 & .109 \\
& Bachelor & 3120 & 13.86 & 3.386 & & \\
Student Teacher Relation & Inter & 430 & 15.20 & 3.188 & .342 & .732 \\
& Bachelor & 3120 & 15.00 & 3.348 & & \\
Management & Inter & 430 & 9.69 & 2.587 & 1.206 & .229 \\
& Bachelor & 3120 & 9.04 & 3.025 & & \\
Contact with Parents & Inter & 430 & 12.71 & 3.443 & 1.239 & .216 \\
& Bachelor & 3120 & 11.90 & 3.690 & & \\
Facilities & Inter & 430 & 6.57 & 2.453 & -.312 & .755 \\
& Bachelor & 3120 & 6.69 & 2.139 & & \\
Total Student Satisfaction & Inter & 430 & 78.14 & 12.994 & 1.456 & .146 \\
& Bachelor & 3120 & 74.42 & 14.499 & & \\
\hline
\end{tabular}


*. $\mathrm{p}<=0.05$

Independent sample $t$-test was applied to compare intermediate and bachelor students' perception towards satisfaction factors. The t-values and mean scores reflected that a meaningful difference was not found in the perception of intermediate and bachelor students' regarding admission process, academic programs, quality of teaching, student teacher relation, management, contact with parents, facilities, overall student satisfaction as the $p$-values $>0.05$

Both intermediate and bachelor students' had perceived almost same level towards admission process, academic programs, quality of teaching, student teacher relation, management, contact with parents, facilities, overall students' satisfaction. It means that without discrimination of other demographics, intermediate and bachelor students in colleges of Lahore division perceived same regarding their satisfaction. Same perceptions at two different levels of programmes i.e. intermediate and bachelors indicated that policies and practices may be same at these both levels.

\section{Discussion and Conclusion}

Quality education is a crucial need of today for survival. With the rapid changes in the various fields of the world, situation is also different in education sector. Asikhia (2010) and Kassim and Abdullah (2010) reported that customers' satisfaction has become a vital indictor of organizational quality performance. Chen (2012) also added by stating that maximization of organizational quality performance relies on the students' satisfaction and retention. He recommended building strong relationship with students for survival. Dadfar, Brege and Sarah (2013) also associated customers' satisfaction with organizational performance. He discussed that establishment of healthy and strong relations with customers' lead to desirable results.

Students participation in college activities is highly appreciated and encouraged in change oriented organizations which bring positive outcomes (Pascarella, Sefifert \& Blaich, 2010). Results and findings in this study are similar to the results published by Ramos et al. (2015) regarding the satisfaction level of students out of their education. Respondents in this study are mostly of the opinion that they are satisfied to their education, teaching, learning, and the overall educational environment at college level in the Lahore division. Research by Ramos et al. (2015) looks at the satisfaction level of students from three perspectives: satisfaction from the program, satisfaction from the institution, and satisfaction from the opportunities for further development. Their results showed much better results that support the satisfaction of students with exception in case of nursing students' satisfaction from their institution of education. 
Study results in Ingusci et al. (2016) supported demographic results in this research article where there are some variations in students' satisfaction out of the education system. Ingusci et al. (2016) also explored that there are possibilities of changes in skills level, knowledge and understanding of subject matter, and variations in teaching with the passage of time or with the involvement of other factors such as gender and satisfaction level.

Results and findings in this research article have slight variations to a research article by James and Casidy (2018) in Australian business education contexts. James \& Casidy (2018) have their focus on the relationships between authentic assessment and students' satisfaction. Their study was based on an online survey in which undergraduates of business education program were respondents. Results in their study showed that there was a strong positive correlation between the authentic assessment and the variables of students' satisfaction and promotion of behaviour in higher education. A look in to variation of results between this research article and the results stated in the published research by James \& Casidy (2018) shows that there is difference of strength of relationship: moderate relationship between quality education and student satisfaction in this study and a strong relationship between authentic assessment and student satisfaction in the study by James \& Casidy (2018).

Ali, Zhou, Hussain, Nair and Ragavan (2016) focused on five aspects of non-academic aspects, academic aspects, reputation, program issues and access to see their impacts on international students' satisfaction in the Malaysian public sector universities. Results in their research are similar to the findings in this study which states that quality of education has moderate positive correlation with the students' satisfaction at college level in Lahore division. Results in this study related to the gender-wise difference in students' satisfaction on quality education at college level in Lahore division are not similar to the survey results in Yusoff, McLeay and Woodruffe-Burton (2015) who showed that there is no significant gender-wise differences in students' satisfaction at private sector higher education institutions in Malaysia.

The results of research conducted by Liu et al. (2016) in Chinese schools have the same results as in this study. They showed that female students are more satisfied with their subjective well-being in schools. On the same parameters, male students in the sample included in their study showed comparatively less satisfaction.

Conclusions of this study about students' satisfaction on the quality education presented a segregated picture. Students were satisfied from their colleges and with the quality of education delivered in these colleges. There was found moderate significant positive correlation between quality education and 
students satisfaction. This means that if there is increase or decrease in quality education in colleges, the satisfaction of the students will inevitably be increased or declined. The students were more satisfied in those colleges where quality education is at its best than the students in those colleges where quality education is not up to the mark.

Female students perceived more satisfaction than male students. It means that female colleges have been more able to meet the satisfaction measures of the students than in male colleges in the division of Lahore. Male and female students considered that colleges offered the same facilities in male and female colleges. There is no significant difference in perception of students regarding students' satisfaction by program wise. It means that intermediate and bachelor students in colleges of the Lahore division experienced the same in terms of their satisfaction without discrimination towards other demographics Similar expectations at two different levels of programmes, i.e. intermediate and bachelor, showed that at both levels, policies and procedures may be the same.

\section{Recommendations}

It is proposed for the review of educational policy makers and other stakeholders that:

1. The positive correlation between students' satisfaction and quality education means that students may be more satisfied. A proper check and balance on male colleges is proposed to implement the quality education indicators because male students were less satisfied than female students.

2. Majority of the students were agreed that they are satisfied with the quality of education in their colleges. A considerable strength of students was unable to understand the indicators of quality education and some of them disagree also. So, there should be counseling sessions, seminars and conferences on regular basis for students.

3. Future researchers may work on this topic with qualitative techniques.

4. Head of the institutions may be included as population in future studies in this regard.

5. This study was on divisional level. In future research and studies may be conducted on broader contexts such as of a province or on national level.

\section{References}

Ali, F., Zhou, Y., Hussain, K., Nair, P.K. \& Ragavan, N.A. (2016). Does higher education service quality effect student satisfaction, image and loyalty? Quality Assurance in Education, 24(1), 70-94. 
Abidin, M. (2015). Higher Education Quality: Perception differences among internal and external stakeholders. International Education Studies, $8(12), 185-192$.

Anderson, E. W., Fornell, C., \& Lehmann, D. R. (1994). Customer satisfaction, market share, and profitability: Findings from Sweden. The Journal of Marketing, 58(1), 53-66.

Asikhia, O. A. (2010). Students and teachers' perception of the causes of poor academic performance in Ogun State secondary schools [Nigeria]: Implications for counseling for national development. European Journal of Social Sciences, 13(2), 229-242.

Aslam, U., Rehman, M., Imran, M., \& Muqadas, F. (2016). The impact of teacher qualifications and experience on student satisfaction: A mediating and moderating research model. Pakistan Journal of Commerce and Social Sciences (PJCSS), 10(3), 505-524.

Belash, O., Popov, M., Ryzhov, N., Ryaskov, Y., Shaposhnikov, S., \& Shestoplalov, M. (2015). Research on university education quality Assurance: Methodology and results of stakeholders' satisfaction monitoring. Procedia-Social and Behavioral Sciences, 214, 344-358.

Boulding, W., Kalra, A., Staelin, R., \& Zeithaml, V. A. (1993). A Dynamic Process Model of Service Quality: From expectations to behavioral intentions. Journal of Marketing Research, 30(1), 7-27.

Budiharso, T., \& Tarman, B. (2020). Improving quality education through better working conditions of academic institutes. Journal of Ethnic and Cultural Studies, 7(1), 99-115.

Chen, S. C. (2012). The customer satisfaction-loyalty relation in an interactive eservice setting: The mediators. Journal of Retailing and Consumer Services, 19(2), 202-210.

Cheng, Y. C. (1995). A Framework of Indicators of Education Quality in Hong Kong Primary Schools: Development and Application. Paper presented at the Asia-Pacific Economic Cooperation Education Forum on SchoolBased Indicators of Effectiveness 
Comm, C. L., \& Mathaisel, D. F. (2000). Assessing employee satisfaction in service firms: An example in higher education. The journal of business and economic studies, 6(1), 43.

Comm, C. L., \& Mathaisel, D. F. (2003). A case study of the implications of faculty workload and compensation for improving academic quality. International Journal of Educational Management, 17(5), 200210.

Creswell, J. W. (2012). Educational Research: Planning, Conducting, and Evaluating Quantitative and Qualitative Research (4 ${ }^{\text {th }}$ ed.). Boston, MA: Pearson.

Dadfar, H., Brege, S., \& Sarah Ebadzadeh Semnani, S. (2013). Customer involvement in service production, delivery and quality: the challenges and opportunities. International Journal of Quality and Service Sciences, 5(1), 46-65.

Fornell, C. (1992). A national customer satisfaction barometer: The Swedish experience. The Journal of Marketing, 56(1) 6-21.

Goetsch, D., \& Davis, S. (2009). Quality Management. Upper Saddle River, N.J.: Pearson Education.

Green, H., Hood, M., \& Neumann, D. (2015). Predictors of student satisfaction with university psychology courses: A review. Psychology Learning \& Teaching, 14(2), 131-146.

Guolla, M. (1999). Assessing the teaching quality to student satisfaction relationship: Applied customer satisfaction research in the classroom. Journal of Marketing Theory and Practice, 7(3), 87-97.

Higher Education Commission (2011). Minimum Quality Standards Manual for Affiliated Colleges. Islamabad: Academic Division.

Higher Education Department (2016). List of Government Colleges in Punjab. Lahore: Administration Division.

Hill, Y., Lomas, L. \& MacGregor, J. (2003). Students' perceptions of quality in higher education. Quality Assurance in Education, 11(1), 15-20. 
Ingusci, E., Callea, A., Chirumbolo, A., \& Urbini, F. (2016). Job crafting and job satisfaction in a sample of Italian teachers: The mediating role of perceived organizational support. Electronic Journal of Applied Statistical Analysis, 9(4), 675-687.

James, L. T., \& Casidy, R. (2018).Authentic assessment in business education: Its effects on student satisfaction and promoting behavior. Studies in Higher Education, 43(3), 401-415.

Kamal, D., Saeed, M. (2018).Relationship between university students' English proficiency, academic achievement and their satisfaction on teacher Feedback. Bulletin of Education and Research, 40(3), 129-143.

Kassim, N., \& Asiah A. N. (2010). The effect of perceived service quality dimensions on customer satisfaction, trust, and loyalty in e-commerce settings: A cross cultural analysis. Asia Pacific Journal of Marketing and Logistics, 22(3), 351-371.

Liu, W., Mei, J., Tian, L., Huebner, E. (2016). Age and gender differences in the relation between school-related social support and subjective well-being in school among students. Social Indicators Research, 125(3), 10651083.

Monazza, A., Rabea, M., Shenila, R., Rose, P., Vignoles, A., \& Whitaker, L. (2019). Methodological lessons on measuring quality teaching in southern contexts, with a focus on India and Pakistan. Research in Comparative and International Education, 14(1), 77-98.

Munteanu, C., Ceobanu, C., Bobâlcă, C. and Anton, O. (2010). An analysis of customer satisfaction in a higher education context. International Journal of Public Sector Management, 23(2), 124-140.

Pascarella, E. T., \& Terenzini, P. T. (2006). How college affects students. Journal of College Student development, 47(5), 508-520.

Ramos, A., Barlem, J., Lunardi, V., Barlem, E., Silveira, R., Bordignon, S. (2015). Satisfaction with academic experience among undergraduate nursing students. Texto \& Contexto-Enfermagem, 24(1), 187-195.

Rehana, R., Ghias, K., Sadia, F., Mehwish, H., Faiza, A. (2016). Students' perception of educational environment at Aga Khan University Medical 
College, Karachi, Pakistan. Pakistan Journal of Medical Sciences, 32(3), 720 .

Saima, S., Kamran, M., Abeer, I., \& Rashid, A. (2017). Service quality and student satisfaction: The moderating role of university culture, reputation and price in education sector of Pakistan. Iranian Journal of Management Studies, 10(1), 237-258.

Shahzad, S. (2007). A study to investigate the quality of education at intermediate level in Punjab (Unpublished doctoral dissertation), University of Arid Agriculture, Rawalpindi.

Shahzad, A., Golamdin, A. G., \& Ismail, N. A. (2016). Opportunity and challenges using the cloud computing in the case of Malaysian higher education institutions. The International Journal of Management Science and Information Technology (IJMSIT), 20, 1-18.

Shields, P.M. \& Rangarajan, N. (2013). A Playbook for Research Methods: Integrating Conceptual Frameworks and Project Management. New Forums Press, Stillwater, OK.

Yusoff, M., Mcleay, F. \& Woodruffe-Burton, H. (2015). Dimensions driving business student satisfaction in higher education. Quality Assurance in Education, 23(1), 86-104.

Zamberi, A. (2015). Evaluating Student Satisfaction of Quality at International Branch Campuses. Assessment and Evaluation in Higher Education, 40(4), 488-507.

\section{Citation of this Article:}

Sadiq, A., \& Akhter, M. M. S. (2021). Analysis of Students' Satisfaction on Quality Education at Government Colleges in Lahore Division. International Journal of Innovation in Teaching and Learning (IJITL), 7(1), 63-78. 